\title{
ESTIMATING THE MICROBIOLOGICAL PURITY OF FROZEN AND DEFROSTED BERRIES
}

\author{
G. Simakhina, S. Khalapsina \\ National University of Food Technologies
}

\begin{tabular}{|c|c|}
\hline Key words: & ABSTRACT \\
\hline $\begin{array}{l}\text { Low temperatures } \\
\text { Microorganisms } \\
\text { Freezing } \\
\text { Cryogenous damages } \\
\text { Defrostation } \\
\text { Quality indices }\end{array}$ & \multirow{3}{*}{$\begin{array}{l}\text { The contemporary stage of food technologies development } \\
\text { reveals the tendency of using the regimes of raw material } \\
\text { procession within the range of low temperatures to be pers- } \\
\text { pective. The authors of the article grounded and experimen- } \\
\text { tally proved the positive influence of cryogenous technologies } \\
\text { on microbiological indices surveyed in frozen and defrosted } \\
\text { fruit and berry half products. There was also shown the } \\
\text { perspectives of preliminary procession of biological objects } \\
\text { with solutions of natural protectors (sorbine and benzoic } \\
\text { acids), which helped decrease the microbiological contamina- } \\
\text { tion of the raw materials. The authors estimated the micro- } \\
\text { biological purity of defrosted berries, considering the different } \\
\text { methods to defrost them and their shelf life in defrosted form. }\end{array}$} \\
\hline $\begin{array}{l}\quad \text { Article history: } \\
\text { Received 13.11.2017 } \\
\text { Received in revised form } \\
27.11 .2017 \\
\text { Accepted 14.12.2017 } \\
\end{array}$ & \\
\hline $\begin{array}{l}\text { Corresponding author: } \\
\text { G. Simakhina } \\
\text { E-mail: } \\
\text { npnuht@ukr.net }\end{array}$ & \\
\hline
\end{tabular}

DOI: $10.24263 / 2225-2924-2017-23-6-16$

\section{ОЦІНКА МІКРОБІОЛОГІЧНОї ЧИСТОТИ ЗАМОРОЖЕНИХ І ДЕФРОСТОВАНИХ ЯГІД}

\section{Г.О. Сімахіна, С.В. Халапсіна \\ Національний університет харчових технологій}

На сучасному етапі розвитку харчових технологій перспективною є тенденція використання процесів з режимами перероблення сільськогосподарської сировини в області низьких температур. У статті обтрунтовано та експериментально підтверджено позитивний вплив холодових технологій на мікробіологічні показники заморожених і дефростованих плодово-ягідних напівфабрикатів. Показано перспективність попереднього оброблення біооб'єктів розчинами природних консервантів - бензойної та сорбінової кислот, завдяки чому вдається знизити мікробіологічну забрудненість матеріалів. Здійснено оцінку мікробіологічної чистоти дефростованих ягід при різних способах розморожування й тривалості зберігання у дефростованому вигляді.

Ключові слова: низькі температури, мікроорганізми, заморожування, кріоушкодження, дефростачія, показники якості.

Постановка проблеми. Харчова сировина та продукти з неї - це складні багатокомпонентні системи із сотень хімічних сполук. Вони включають 
аліментарні сполуки, умовно неаліментарні й чужорідні, потенційно небезпечні речовини антропогенного та природного походження. Плоди та ягоди характеризуються високим вмістом води (до 90 \%) й органічних сполук, тому вони є сприятливим середовищем для росту і розмноження мікроорганізмів. Це стосується і свіжої, й замороженої сировини. Причому на поверхні заморожених i дефростованих плодово-ягідних напівфабрикатів виявляють в основному ті ж мікроорганізми, що й на свіжій сировині. Цілий ряд мікроорганізмів потрапляє на поверхню плодів та ягід із грунту і повітря. На плодах, що мають порівняно низьке значення $\mathrm{pH}$, розмножуються здебільшого дріжджі та міцеліальні гриби. Тут знаходять гриби Aspergillus, Penicillum, Cladosporium, Fusarium, Alternarium, Rhizopus, Mucor, Botritis та Oospora; дріжджі Saccharomyces i Torula, бактерії Bacillus stearothermophilus, Bacillus subtilis i Staphilococcus aureus.

Мікроорганізми легко пристосовуються до змін навколишнього середовища. Відповідно до літературних даних (Е. Алмаші, 1981), заморожування сільськогосподарської сировини рідким азотом не приводить до повної загибелі мікроорганізмів, а деякі з них можуть зберігати свою життєздатність протягом кількох років. Серед них є і такі представники, що не гинуть навіть після 100-кратного заморожування та розморожування (Л.К. Лозина-Лозинський, 1982). Більш того, за даними Е. Алмаші та інших дослідників, загибель мікроорганізмів істотно менша при температурах $-20 \ldots-25^{\circ} \mathrm{C}$, ніж при $-5 \ldots-12^{\circ} \mathrm{C}$.

Дослідження, проведені проф. Р.Ю. Павлюк зі співробітниками [1], показали, що основними групами мікроорганізмів, які трапляються у плодоовочевій сировині та продуктах ії перероблення, $є$ бактерії та мікроскопічні гриби.

За реакцією на температуру бактерії умовно поділяють на термофільні (теплолюбні), мезофільні (адаптовані до середніх температур) та психрофільні (холодолюбні). Оптимальною температурою розвитку термофільних бактерій є $50 \ldots 60^{\circ} \mathrm{C}$, мезофільних $-25 \ldots 30^{\circ} \mathrm{C}$, психрофільних $-5 \ldots 20^{\circ} \mathrm{C}$. Однак деякі види психрофільних бактерій можуть розвиватись і при температурах $-5 \ldots-8^{\circ} \mathrm{C}[2]$. Слід додати також, що бактерії розвиваються лише на тих харчових середовищах, які містять не менш ніж 20\% води.

Мікроскопічні гриби представлено дріжджами (одноклітинні нерухомі організми) та пліснявою (нижчі рослини одноклітинної та багатоклітинної будови). Плісняві гриби розвиваються лише за наявності кисню шляхом спороутворення, i цей процес може здійснюватись при температурах до $-11^{\circ} \mathrm{C}$. плісняві гриби мають високу ферментативну активність, викликають глибоку денатурацію білків і жирів. Тому оцінка мікробіологічної безпеки - надзвичайно важливий чинник, який характеризує якість сировини і готових продуктів. Для України як держави, орієнтованої на експорт сільськогосподарської продукції [3], дотримання необхідних показників безпеки $є$ основною умовою виходу на європейський ринок.

Аналіз останніх досліджень і публікацій. За результатами моніторингу ще наприкінці XX століття було визначено перелік пріоритетних забруднювачів, які підлягають контролю в різних групах продовольчої сировини та харчових продуктів. Відповідно до цього переліку, плодово-ягідна сировина i 
продукти 3 неї мають контролюватись передусім за вмістом мезофільно аеробних i факультативно анаеробних мікроорганізмів (МАФАнМ), що виражається в 1 г або 1 см$^{3}$ продукту; патогенних мікроорганізмів, бактерій, дріжджів, плісняви. Велику небезпеку з точки зору токсичності має патулін. Він продукується пеніцилами й аспергилами та виявляється переважно у продуктах, отриманих із неякісних фруктів і ягід.

Система заходів профілактики виникнення та накопичення мікотоксинів включає санітарно-мікологічний аналіз досліджуваних продуктів, до складу якого входить органолептична характеристика, визначення ступеня токсичності біологічними методами, посів на живильні середовища для вивчення мікрофлори, визначення вмісту токсинів хімічними методами. Разом 3 тим при переробленні сільськогосподарської сировини, в тому числі плодовоягідної, значну увагу приділяють способам її деконтамінації та детоксикації, а також готових продуктів, уражених мікотоксинами. 3 цією метою використовують механічні, фізичні та хімічні методи [4].

Механічні методи очищення плодово-ягідної сировини полягають у видаленні забруднених матеріалів вручну або за допомогою електронно-калориметричних пристроїв. При фізичному способі здійснюють термічне оброблення або ультрафіолетове опромінення; хімічному - обробляють ягоди та фрукти розчинами окислювачів, сильних кислот або основ. Аналіз ефективності цих методів показав, що перший не дає належних результатів, а хімічні методи, окрім усього, призводять до руйнування не лише мікотокиснів, а й корисних нутрієнтів сировини і порушують їх усмоктування в організмі людини.

I недаремно такої широкої популярності набув сьогодні фізичний метод деконтамінації сільськогосподарської сировини, який грунтується на використанні низьких температур. Як і будь-яка прикладна галузь знань, холодильна технологія зобов'язана своїм становленням, розвитком і вдосконаленням практичним потребам харчової промисловості: необхідності отримання консервованої продукції високої якості з максимальним збереженням усього комплексу біологічно активних речовин, синтезованих у сировині природою; можливості тривалого зберігання такої продукції без погіршення іiі біохімічних та органолептичних показників, що загалом гарантує постачання населенню високовітамінної продукції впродовж цілого року.

У нинішніх умовах штучний холод завоював своє пріоритетне місце серед інших способів перероблення та зберігання плодоовочевої сировини. I тому цей напрям $є$ предметом особливої уваги науковців і практиків.

У праці видатного вченого Б. Флауменбаума [5] зазначається, що різке зниження температури при заморожуванні сировини приводить до переходу вологи 3 рідкого у твердий стан, унаслідок чого живлення мікроорганізмів припиняється, оскільки воно відбувається всмоктуванням рідких живильних середовищ. Установлено [6], що найстійкішими до низьких температур є плісняві гриби та дріжджі, а найбільш чутливими - бактерії, які не утворюють спор. Водночас усі автори зазначають, що повного відмирання мікроорганізмів при заморожуванні практично не відбувається.

Виявлено, що стійкість мікроорганізмів до негативних температур залежить від ряду чинників: величини кристалів льоду, температури, швидкості їі 
зниження, тривалості впливу, реакції середовища. Під дією цих чинників, як і для всіх біологічних об'єктів, відбувається кріоушкодження клітин та їх руйнування. Відповідно до концепції Б. Люйє (1930-1940), в основі руйнування будь-яких біологічних об'єктів лежить один фундаментальний факт: утворення поза- або внутрішньоклітинних кристалів льоду, які й ініціюють усі кріоушкодження клітинних структур.

Згідно з дослідженнями П. Мейзура (1966-1974), при повільному заморожуванні процес кристалізації води відбувається переважно у міжклітинному просторі, оскільки вода встигає покинути клітини. Вона частково дегідратована, і при замерзанні ріст внутрішньоклітинних кристалів льоду не відбувається - росте позаклітинний лід у вигляді великих кристалів, які й викликають руйнування протоплазми і клітинних оболонок мікроорганізмів. При швидкому заморожуванні переохолоджена вода не встигає мігрувати 3 клітин, унаслідок чого зростає кількість зародків надзвичайно дрібних внутрішньоклітинних кристалів льоду (10...40 мкм), не здатних спричинити механічне руйнування клітинних структур.

Проф. Р.Ю. Павлюк наводить результати експериментальних досліджень [1], згідно з якими при заморожуванні фруктів та овочів рідким азотом із високою швидкістю охолодження (10..20) ${ }^{\circ} \mathrm{C} / \mathrm{xв}$ до кінцевої температури $-40^{\circ} \mathrm{C}$ викликає зменшення кількості мікроорганізмів на $38 \ldots 65 \%$. Заморожування в діапазоні швидкостей від 1 до $10{ }^{\circ} \mathrm{C} /$ хв до температури $-10 \ldots-20^{\circ} \mathrm{C}$ сприяє загибелі всього 4..11\% мікроорганізмів. Хоча, за даними Е. Алмаші та Ф. Мещерякова (1975), найбільша кількість мікробних клітин руйнується саме в інтервалі температур $-5 \ldots-12^{\circ} \mathrm{C}$.

Викладення основних результатів дочлідження. Мікробіологічні дослідження на наявність у сировині та заморожених напівфабрикатах патогенних мікроорганізмів, бактерій, дріжджів, плісняви здійснювали методами, передбаченими в ГОСТах: 1044.15-94; 10444.12-88; 26670-91, 30518-91. Аналізи проводили чашковим способом кількісного обліку на твердих живильних середовищах. Загальну кількість бактерій визначали на м'ясо-пептонному агарі, кількість пліснявих грибів і дріжджів - на сусло-агарі.

Для дослідження обрано ягоди малини (як представника культивованих рослин) та ягоди ожини (дикорослі). Ягоди після попередньої підготовки упаковували у поліетиленові пакети завтовшки 30..60 мкм, герметизували шляхом термозварювання, заморожували у морозильній установці при темпеpaтурі $-35 \ldots-37^{\circ} \mathrm{C}$ і зберігали в морозильній камері протягом певного періоду при $-18^{\circ} \mathrm{C}$. Частину ягід перед заморожуванням обробляли розчином, до складу якого входять сорбінова та бензойна кислоти. Це природні консерванти, які широко використовуються у плодоовочевій промисловості для запобігання мікробіологічному псуванню продукції. Їх додавання затримує розвиток мікроорганізмів і викликає їхню часткову загибель.

Сорбінова та бензойна кислоти синтезуються в ягодах журавлини, брусниці тощо, і це забезпечує їх тривале зберігання у звичайних умовах упродовж тривалого терміну.

За результатами досліджень науковців ВНДІ консервної та овочесушильної промисловості [7], добавки сорбінової кислоти $\left(\mathrm{C}_{5} \mathrm{H}_{7} \mathrm{COOH}\right)$ або бензой- 
ної $\left(\mathrm{C}_{6} \mathrm{H}_{5} \mathrm{COOH}\right)$ до консервованої продукції затримують розвиток пліснявих грибів і дріжджів у 1,5 ..1,9 раза ефективніше, ніж нові синтетичні консерванти (парабени, юглон тощо). Причому для інгібування розвитку дріжджів концентрація кожного 3 консервантів має бути в $2 \ldots 4$ рази більшою, ніж для пліснявих грибів. Ми скористалися рекомендаціями авторів статті щодо концентрації сорбінової та бензойної кислот у розчинах для попереднього оброблення ягід перед заморожуванням: вона становить, відповідно, $0,05 \%$ та $0,14 \%$.

Мікробіологічні дослідження дослідних зразків ягід проводили відразу після заморожування, після дефростації і зберігання в дефростованому вигляді у холодильній камері при температурі $3 \ldots 5^{\circ} \mathrm{C}$ протягом певного часу. Показники визначали в середній пробі зразків у триразовій повторюваності. У табл. 1 наведено результати оцінки мікробіологічної чистоти ягід малини та ожини безпосередньо після заморожування.

Таблиця 1. Рівень мікробіологічної чистоти ягід після заморожування

\begin{tabular}{|c|c|c|c|c|c|}
\hline \multirow[b]{2}{*}{ Показник } & \multirow{2}{*}{$\begin{array}{c}\text { Гігієнічний } \\
\text { норматив }\end{array}$} & \multicolumn{2}{|c|}{ Ягоди малини } & \multicolumn{2}{|c|}{ Ягоди ожини } \\
\hline & & Необроблені & $\begin{array}{c}\text { Оброб- } \\
\text { лені }\end{array}$ & $\begin{array}{l}\text { Необ- } \\
\text { роблені }\end{array}$ & $\begin{array}{c}\text { Оброб- } \\
\text { лені }\end{array}$ \\
\hline $\begin{array}{l}\text { КМАФАнМ, } \\
\text { КУО/Г }\end{array}$ & $5,0 \cdot 10^{4}$ & $2,9 \cdot 10^{2}$ & $2,1 \cdot 10^{2}$ & $4,3 \cdot 10^{2}$ & $2,8 \cdot 10^{2}$ \\
\hline $\begin{array}{c}\text { БГКП (коліформи) } \\
\text { в } 0,1 \text { г }\end{array}$ & Не допускається & Не виявлено & Не виявлено & $\begin{array}{c}\text { Не } \\
\text { виявлено }\end{array}$ & $\begin{array}{c}\text { Не } \\
\text { виявлено }\end{array}$ \\
\hline Плісені, КУО/г & $5,0 \cdot 10^{2}$ & $1,0 \cdot 10^{1}$ & Не виявлено & $1,0 \cdot 10^{1}$ & $\begin{array}{c}\text { Не } \\
\text { виявлено }\end{array}$ \\
\hline Дріжджі, КУО/г & $2,0 \cdot 10^{2}$ & Не виявлено & Не виявлено & $1,0 \cdot 10^{1}$ & $\begin{array}{c}\text { Не } \\
\text { виявлено }\end{array}$ \\
\hline
\end{tabular}

Передусім слід зазначити, що патогенних мікроорганізмів, у тому числі бактерій роду Salmonella (у 25 г) ні у свіжих ягодах, ні у заморожених напівфабрикатах не виявлено.

Відповідно до наведених результатів, у досліджуваних об'єктах відсутні також бактерії групи кишкових паличок (коліформи). Дріжджі виявлено лише у зразку ягід ожини, необроблених розчином суміші сорбінової та бензойної кислот, однак їхня кількість у 20 разів менша від гігієнічного нормативу. Кількість МАФАнМ у ягодах ожини $\left(4,3 \cdot 10^{2}\right)$ вища, ніж у малині $\left(2,9 \cdot 10^{2}\right)$. I для кожного виду ягід очевидним $€$ позитивний ефект оброблення перед заморожуванням розчинами природних консервантів. Завдяки цьому кількість МАФАнМ для ягід малини зменшується на 27,6\%, а для ожини - на $34,9 \%$. Плісняві гриби у невеликих кількостях виявлено лише в ягодах, необроблених консервантами.

Загалом унаслідок заморожування ягід кількість мікроорганізмів зменшується на $28 . .56 \%$, що узгоджується з результатами досліджень інших авторів. Це при тому, що заморожування вели методом швидкого зниження температури, при якій утворений дрібнокристалічний лід незначно руйнує плазматичні мембрани та клітинні оболонки як об'єктів заморожування, так і мікроорганізмів.

Щоб пояснити позитивний вплив заморожування (незалежно від способів його реалізації) на підвищення мікробіологічної чистоти плодово-ягідної 
сировини, необхідно ввести поняття «температурний шок клітини». Під цим поняттям автори $[6 ; 8]$ розуміють стан структурного руйнування плазматичної мембрани або клітини в цілому, яке відбувається після швидкого зниження температури до $0^{\circ} \mathrm{C}$ і нижче. За спостереженнями А. Білоуса та В. Грищенка [8], швидкість руйнування клітин залежить передусім від вмісту холестерину в мембранах. Більшість мікроорганізмів належать до об'єктів із незначною концентрацією холестерину, тому їхні клітинні структури здатні руйнуватись уже після швидкого охолодження.

Таким чином, вплив заморожування біоматеріалів з використанням низьких температур на руйнування мікроорганізмів варто розглядати 3 двох позицій: ушкодження їхніх клітинних структур, пов'язані з деструктивною дією утворених позаклітинних або внутрішньоклітинних кристалів льоду, і ушкодження, викликані розвитком температурного шоку. I оскільки в мембранах мікроорганізмів мало холестерину, який сприяє жорсткому зв'язуванню ліпідів у стабільні холестерин-фосфоліпідні кластери [9], стійкі до дії температурного шоку, бар'єрні властивості порушуються і холодовий шок розвивається в зоні помірно низьких температур.

Слід зазначити, що у кріобіології [8] до низьких температур відносять інтервал від 0 до $-273^{\circ} \mathrm{C}$.

Відомо, що істотних змін зазнають компоненти заморожених напівфабрикатів при дефростації. Більшість цих змін мають негативний характер, тому необхідними $є$ дослідження впливу способів розморожування на показники мікробіологічної безпеки. Отримані результати наведено у табл. 2. Досліджували ягоди ожини, оброблені перед заморожуванням розчинами сорбінової та бензойної кислот, і дефростованих через 6 місяців зберігання при температурі $-18{ }^{\circ} \mathrm{C}$.

Дефростацію проводили 4 способами: 1 спосіб - на повітрі при температурі $18 \ldots 22^{\circ} \mathrm{C} ; 2$ спосіб - у мікрохвильовій печі; 3 спосіб - у холодильній камері при $0^{\circ} \mathrm{C} ; 4$ спосіб - у водяній бані при $37 \ldots 42^{\circ} \mathrm{C}$.

Згідно $з$ даними, у заморожених напівфабрикатах через 6 місяців зберігання не виявлено ні БГКП, ні пліснявих грибів, ні дріжджів. Навпаки, при зберіганні заморожених ягід при температурі $-18^{\circ}$ С кількість МАФАнМ зменшилась на 19,6\%. Подібну тенденцію спостерігали й інші автори [10]. Тобто руйнівний вплив заморожування на мікроорганізми продовжується і в процесі низькотемпературного зберігання. Це апріорі свідчить про те, що мікрофлора плодів та ягід представлена організмами з низьким вмістом холестерину, і холодовий шок виявляє свою дію тривалий час, призводячи поступово все більше клітин до втрати життєздатності.

Таблиия 2. Рівень мікробіологічної чистоти ягід ожини, дефростованих різними способами

\begin{tabular}{|c|c|c|c|c|}
\hline Досліджувані зразки & $\begin{array}{c}\text { КМАФАнМ, КУО /БГКП (коліформи), } \\
\text { в } 1 \text { г }\end{array}$ & $\begin{array}{c}\text { Плісняві } \\
\text { гриби, } \\
\text { КУО / }\end{array}$ & $\begin{array}{c}\text { Дріжджі, } \\
\text { КУО / г }\end{array}$ \\
\hline 1 & 2 & 3 & 4 & 5 \\
\hline $\begin{array}{c}\text { Заморожені ягоди } \\
\text { (контроль) }\end{array}$ & $2,8 \cdot 10^{2}$ & Не виявлено & Не виявлено & Не виявлено \\
\hline
\end{tabular}


Продовження табл. 2.

\begin{tabular}{|c|c|c|c|c|}
\hline 1 & 2 & 3 & 4 & 5 \\
\hline $\begin{array}{c}\text { Заморожені ягоди } \\
\text { через 6 місяців } \\
\text { зберігання }\end{array}$ & $2,3 \cdot 10^{2}$ & Не виявлено & Не виявлено & Не виявлено \\
\hline За способом 1 & $2,3 \cdot 10^{2}$ & Не виявлено & Не виявлено & Не виявлено \\
\hline За способом 2 & $2,3 \cdot 10^{2}$ & Не виявлено & Не виявлено & Не виявлено \\
\hline За способом 3 & $2,0 \cdot 10^{2}$ & Не виявлено & Не виявлено & Не виявлено \\
\hline За способом 4 & $2,3 \cdot 10^{2}$ & Не виявлено & Не виявлено & Не виявлено \\
\hline
\end{tabular}

Отримані результати показали також, що спосіб дефростації майже не впливає на рівень мікробіологічної чистоти напівфабрикатів, за винятком способу 3 - відігрів у холодильній камері. Очевидно, тут знову спрацьовує ефект температурного шоку, і кількість мікроорганізмів зменшується ще на $13 \%$. Для вибору найкращого варіанта розморожування необхідні подальші дослідження із з'ясування кількості втраченого при дефростації соку та біологічно активних речовин, вологоутримуючої здатності ягід тощо.

Цікаво також простежити за динамікою зміни мікробіологічних показників у дефростованих ягодах протягом певного періоду зберігання. Для цього дефростовані ягоди зберігали у холодильній камері при температурі $5 \ldots 6^{\circ} \mathrm{C}$ протяом 2, 24 і 36 годин. Результати наведено у табл. 3. Дефростацію ягід проводили у холодильній камері при $0^{\circ} \mathrm{C}$.

Згідно з табличними даними, протягом першої доби зберігання дефростованих ягід з'явилась невелика кількість дріжджів, яка збільшилась до кінця зберігання до $3,0 \cdot 10^{1} \mathrm{KУO} \mathrm{/} \mathrm{г,} \mathrm{однак} \mathrm{ця} \mathrm{величина} \mathrm{значно} \mathrm{менша} \mathrm{від} \mathrm{гігієніч-}$ ного нормативу $\left(2,0 \cdot 10^{2}\right)$. Ні патогенних мікроорганізмів, ні коліформ, ні пліснявих грибів за досліджений термін у ягодах не виявлено.

Таблиця 3. Вплив тривалості зберігання дефростованих ягід ожини на рівень мікробіологічної чистоти

\begin{tabular}{|c|c|c|c|c|c|}
\hline $\begin{array}{c}\text { Досліджувані } \\
\text { зразки }\end{array}$ & $\begin{array}{c}\text { Тривалість } \\
\text { зберігання, } \\
\text { години }\end{array}$ & $\begin{array}{c}\text { КМАФАнМ, } \\
\text { КУО/Г }\end{array}$ & $\begin{array}{c}\text { БГКП } \\
\text { (коліформи), } \\
\text { в } 1 \text { г }\end{array}$ & $\begin{array}{l}\text { Плісняві } \\
\text { гриби, } \\
\text { КУО / г }\end{array}$ & $\begin{array}{l}\text { Дріжджі, } \\
\text { КУО / г }\end{array}$ \\
\hline $\begin{array}{c}\text { Заморожені } \\
\text { ягоди (контроль) }\end{array}$ & - & $2,8 \cdot 10^{2}$ & Не виявлено & Не виявлено & Не виявлено \\
\hline $\begin{array}{c}\text { Заморожені } \\
\text { ягоди через } \\
6 \text { місяців } \\
\text { зберігання }\end{array}$ & - & $2,3 \cdot 10^{2}$ & Не виявлено & Не виявлено & Не виявлено \\
\hline \multirow{3}{*}{$\begin{array}{c}\text { Дефростовані } \\
\text { ягоди }\end{array}$} & 2 & $2,0 \cdot 10^{2}$ & Не виявлено & \multicolumn{2}{|c|}{ Не виявленоНе виявлено } \\
\hline & 24 & $2,0 \cdot 10^{2}$ & Не виявлено & Не виявлено & $1,0 \cdot 10^{1}$ \\
\hline & 36 & $2,0 \cdot 10^{2}$ & Не виявлено & Не виявлено & $3,0 \cdot 10^{1}$ \\
\hline
\end{tabular}

\section{Висновки}

Перспективи широкого впровадження низькотемпературних технологій у харчовій промисловості грунтуються на вивченні цілого комплексу питань, пов'язаних із доцільністю, ефективністю та економічністю їх використання. У межах дослідження 3'ясовано вплив низькотемпературних технологій на показники безпеки напівфабрикатів, передусім пов’язаних із їхньою мікро- 
біологічною чистотою. Умови проведення низькотемпературних процесів справляють позитивний вплив на зниження мікробіологічної забрудненості плодово-ягідної сировини при іï заморожуванні, зберіганні та дефростації. На загибель мікроорганізмів при заморожуванні впливають температура i тривалість процесу, реакція середовища, швидкість заморожування і залежна від цього структура кристалів льоду. 3'ясовано роль температурного шоку на руйнування плазматичних мембран та клітинних структур мікроорганізмів. Способи дефростації практично не впливають на рівень мікробіологічної чистоти матеріалів. Це дає підстави стверджувати, що запропонована технологія заморожування, зберігання та дефростації плодово-ягідних напівфабрикатів відповідає гігієнічним нормативам стосовно безпеки харчових продуктів. Природні антисептики - бензойну та сорбінову кислоти - доцільно використовувати для попереднього оброблення біооб'єктів перед заморожуванням.

\section{Література}

1. Новые технологии витаминных углеводсодержащих фитодобавок и их использование в продуктах профилактического действия : монография / Р.Ю. Павлюк, А.И. Черевко, И.С. Гулый и др. - Харьков ; Киев, 1997. — 285 с.

2. Мікробіологія харчових виробництв: навч. посіб. / Т.П. Пирог, Л.Р. Решетняк, В.М. Поводзинський, Н.М. Грегірчак. - Вінниця : Нова книга, 2007. — 464 с.

3. Єдина комплексна стратегія розвитку сільського господарства та сільських територій на 2015-2020 роки [Електронний ресурс]. — Режим доступу : http://minagro.gov.ua/node16025.

4. Позняковский В.М. Гигиенические основы питания, безопасность и экспертиза продовольственных товаров : учебник / В.М. Позняковский. - 2-е изд. - Новосибирск : Изд-во Новосиб. ун-та, 1999. - 448 с.

5. Флауменбаум Б.Л. Основы консервирования пищевых продуктов / Б.Л. Флауменбаум. - Москва : Легкая и пищ. пром-сть, 1982. - 268 с.

6. Головкин Н.А. Холодильная технология пищевых продуктов. - Ч. 1 / Н.А. Головкин. - Москва : Пищ. промышленность, 1984. - 240 с.

7. Подлесный А.Н. Консерванты в плодоовощной промышленности / А.Н. Подлесный, В.А. Ломачинский, О.И. Квасенков // Пищевая промышленность. — 2006. — № 2. C. $54-55$.

8. Белоус А.M. Криобиология : монография / А.М. Белоус, В.И. Грищенко. Киев : Наукова думка, 1994. — 432 с.

9. Гонський Я.І. Біохімія людини : підручник / Я.І. Гонський, Т.П. Максимчук, М.І. Калинський. - Тернопіль : Укрмедкнига, 2002. - 744 с.

10. Борш Г.Г. Вплив заморожування та холодильного зберігання овочів на життєдіяльність мікроорганізмів / Г.Г. Борщ, С.О. Белінська // Проблеми харчування. — 2003. № $7 .-$ C. $71-73$. 